\title{
多層アンカー仕上げ坑井の産量推定シミュレーター*
}

\author{
田崎 義 行 ${ }^{* *}$
}

(平成元年 7 月 31 日受付, 9 月 8 日受理)

\section{A Simulator to Predict Production Rates of Long Perforated-Pipes Wells}

By

\author{
Tazaki YosHIYUKI
}

\begin{abstract}
The deposits of Minami Kanto gas field is very thick and reserves amout of methane and iodine. Production wells are completed with long perforated pipes. Most of these wells are tubingless and the artificial lift method is continuous gas lift.

I have developed a simulator which is formed with a three dimensional, two-phase double porosity reservoir model and a gas lift program. Using this simulator, production rates of wells can be predicted and production tests are analized exactly.
\end{abstract}

\section{1.はじめに}

南関東ガス田の鉱床を形成する上総層群は未固結な砂 岩と泥岩の互層であり，そこにメタンとよう素を溶解し たかん水が存在する。この鉱床から水溶性ガスとよう素 を営利的に採取するには大量のかん水を没み上げる必要 があり，採収方法として水中電動ポンプ又はガスリフト を使う。坑井は一般に長孔明管といわれる数百メートル 以上の長さを持つアンカーパイプで多層を同時に仕上げ ている。

複数の層から同時に生産するとき，地層の圧力やガス の飽和率，浸透率，有効層厚といったパラメータが各層 で異なるため生産量の予測が困難であった。また，仕上 げ層の重複する生産井や圧入井の干路により貯留層内で の流れが複雑となり，それが生産量に大きく影響する。 そこで貯留層から坑井そしてフローラインを通りセパレー ターに達する水ガス 2 相の流れの圧力損失を計算し, 詝 留屏の排出エネルギー及び坑井の生産能力にあった各仕 上げ層からの水とガスの産出量を求めるシミュレーター を開発した。

このシミュレーターは田崎（1988）が南関東ガス田を

*平成元年 6 月 7 日 第54回石油技術協会総会開発·生産部門シ ンポジウム「人口採油・採収技術」講演

**関東天然瓦斯開発(稆) 茂原鉱業所
対象として開発した 3 次元 2 相でダブルポロシティ・タ イプの眝留層モデルと外吹き込み方式ガスリフトのプロ グラムを組み合わせたものである。外吹き込み方式ガス リフトのプログラムについては杉原 (1987) 紹介している。 ここでは多層アンカー仕上げの坑井に外吹き込み方式 でガスリフトを掛けるといった南関東ガス田独特の採収 方法とその機構を数值モデル化したシミュレーターにつ いて概要を説明する。さらにシミュレーターの使用例と して生産量の予測, 坑井の設計そして坑井テストの解析 を行う。

\section{2. 採収方法}

水溶性ガス田でかん水を汲み上げる方法として主なる のに水中電動ポンプとガスリフトの 2 種類がある。水中 電動ポンプは通常型ガス田によく使われる。通常型ガス 田ではガス水比が溶解ガス水比に近い小さな值で，ガス の絡みによる效率減退の心配がないからである。逆に茂 原型ガス田にはガスリフトが使われる。ガスリフトは外 吹き込み方式を採用しているのでガス水比が上昇して自 噴が始まるときに人工採收加ら自噴採収への切り換えが 容易にできるという利点を持つ。自噴採収から人工採收 への切り換えも同様である。

外吹き込み力式ガスリフトの採収機構を図 1 に示す。 この採収方法で汲み上げるとき流体の流れは次の上うに 


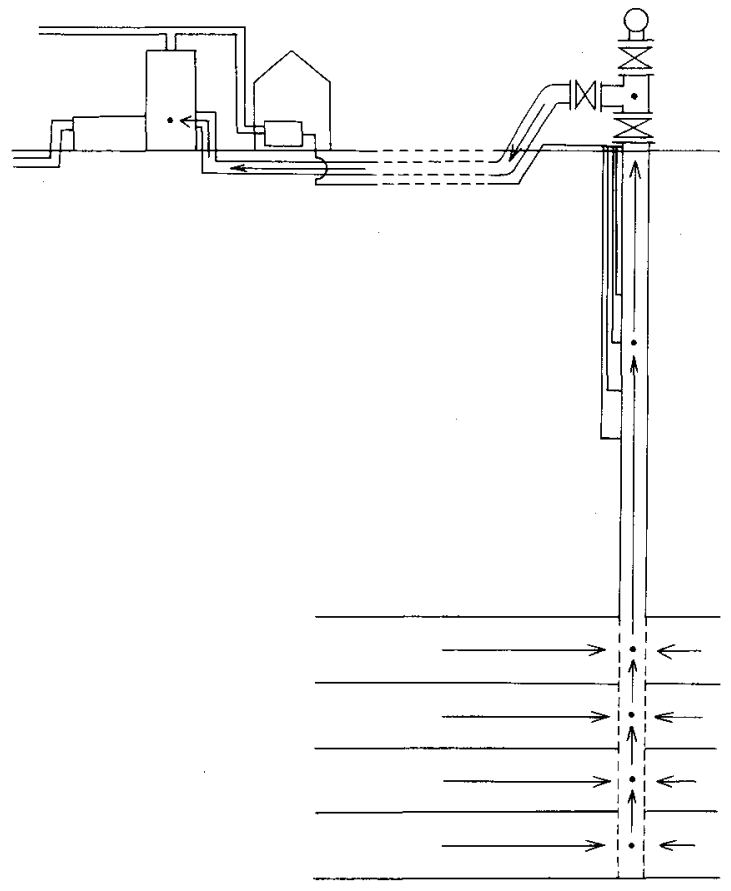

図 1 採収機構

なる。

眝留層から坑底に流入した水とガスはアンカーパイプ とそれに直結したケーシングを上昇し，ガス吹き込み管 の接続口でガスリフトを掛けられ流速を增して坑口に達 する。さらに坑口からフローラインを通ってセパレーター まで 2 相で流れる。セパレーターで水とガスは分離され るが，そのときのセパレータ一背压力は大気圧より僅か に高い程度で, 水柱にして $1 \mathrm{~m}$ 前後と考えてよい。分離 された水は沈砂槽で砂粒子を落とし, 排水管でヨード工 場に送られる。ガスの一部は圧縮機で加圧されガスリフ ト用に使われる。残りのガスが生産ガスとして集ガスラ インに乗る。

外吹き込み方式のガスリフトを採用するためには坑井 を仕上げる段階で吹き込み深度を決め，その深度のケー シングに吹き込み口を開けガス吹き込み管を外側から接 続して,ケーシングに添わせて降管する。通常, 4 本の ガス吹き込み管をほぼ等間隔に接続する。生産が進み水 位が低下すると地上のバルブを操作して吹き込み深度を 切り換える。ガス吹き込み管が 4 本に限定されるため, 吹き込み深度の決定は重要で, ケーシングの径や圧縮機 の能力と併せて慎重に決めなければならない。外吹き込 み方式ガスリフトではチュービングを使わず，ケーシン グそのあのを揚水管としていることからあ，この方式の ガスリフトを設計することは取りあ直さず坑井そのもの
を設計することになる。

\section{3. 産量推定シミュレーター}

\section{1 数值モデル化}

眝留層に㩔削された坑井で生産を行うときに生じる水 ガス 2 相の流れを BROWN（1977）を参考に数值モデル 化しシミェレーターとして使えるようにした。シミュレー ターの流れ図を図 2 に示し概略を説明する。

最初に眝留層データと坑井データを入力する。眝留層 データの主なものには地層の深度と構造, 孔隙率, 浸透 率，そして圧縮率などが上げられる。茂原ガス田はダブ ルポロシティ・タイプであるから砂岩と泥岩の岩質を入 力する。坑井データとしてはケーシングの径, 圧縮機の 機種，ガス吹き込み深度といったものがある。

各種データの入力後, 初期化として地層条件を設定す る。ここでは開発初期の地層圧及び砂岩と泥岩に存在す るガスの飽和率を入力することになっている。

次に生産圧入ループに入る。各坑井の生産又は圧入力 式をコード(NCODE)で入力し，コード番号に従って各 仕上げ層の産出量又は圧入量, 坑底圧を計算する形になっ ている。NCODEが1のときは自噴のみによって生産 が行われるとして, 生産量や各仕上げ層の産出量, 坑底 圧を計算する。NCODEが 2 のときはガスリフト採収 で，ガス吹き込み段数を指定し生産量などを求め る。NCODEが3のときは自噴又はガスリフト採収で 最它生産量の大きいケースを自動的に選択し，そのとき の各仕上げ層の産出量や坑底圧を計算する。NCODE が 4 のときは生産水量を指定し, ガスの生産量, 各仕上 げ層の産出量, 坑底圧を求める。压入力式は 2 種類ある。 NCODE が-1のときは坑口压を指定し, 全压入水量之 各仕上げ層の压入水量, 坑底厓を計算する。 NCODE がー4のときは逆に全圧入水量を入力し, 計算でそれを 各仕上げ層に振り分けるととあに坑底圧を求める。

以上のように各坑井の生産圧入方式が指定されると, それに従って各坑井の水及びガスの産出量又は压入水量 が仕上げ層ごとに計算される。

全坑井の生産量又は圧入量が求められると, それに伴 う地層圧の変化を計算し，さらにガスの飽和率を計算す る。計算結果は出力コードに従って出力され,つぎの夕 イムステップヘと進む。そして再び坑井の生産量又は压 入量を計算する。

このように産量推定シミュレーターは地層圧とガスの 飽和率の変化を追いながら，坑井の生産量又は压入量を 求めていく経時的なシミュレーターである。

\section{2 産出量の計算手順}

多層アンカー仕上げ坑井で生産を行うとき, 個々の仕 


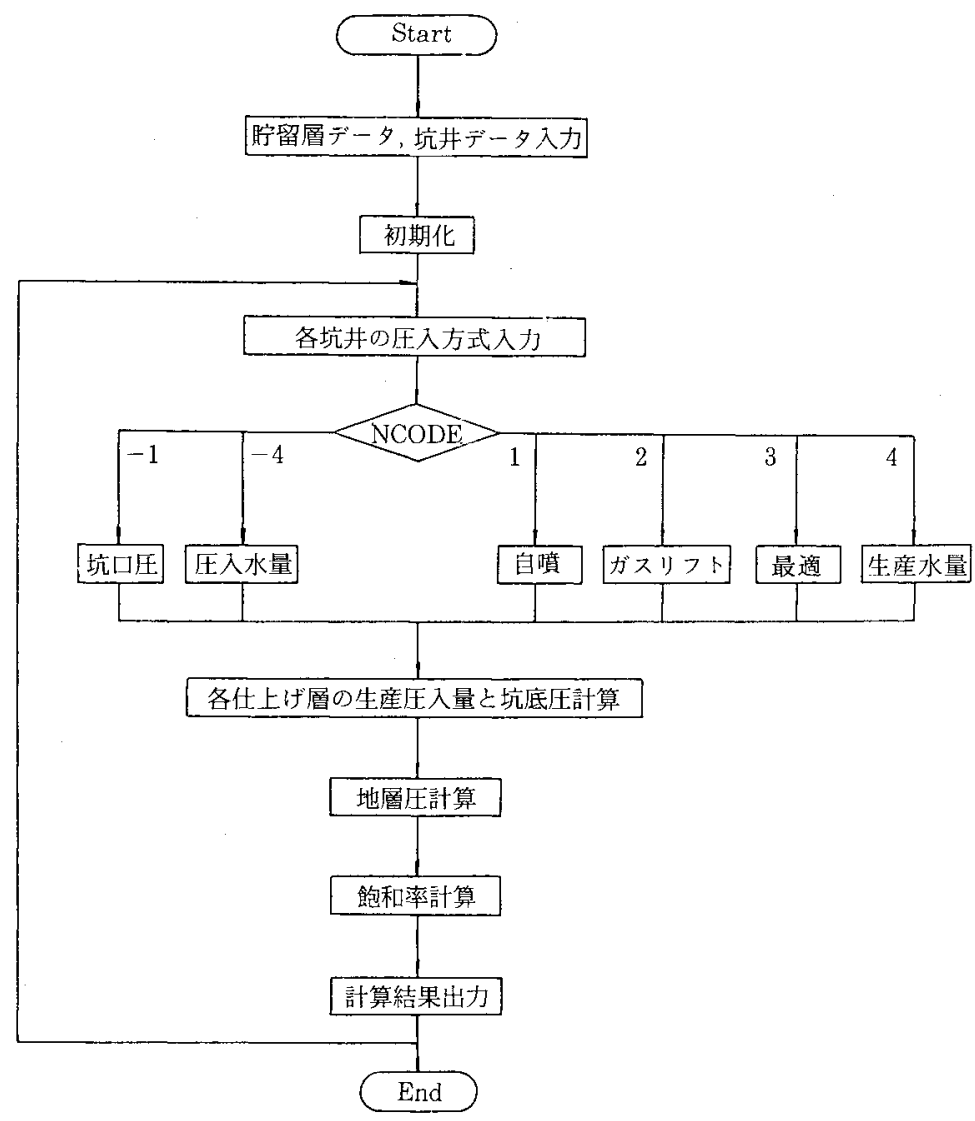

図 2 流れ 図

上げ層からの流体の流れをコントロールすることはでき ない。すなわち，ある水量を生産するとき各仕上げ層か ら産出する水及びガスの量は压力バランスが保てるよう に一義的に決まる。シミュレーターではこういった各仕 上げ層からの産出量と坑底圧をどのように求めていくか 以下に手順を示す。

1. 水の生産量 QWT 設定する。

2. 各仕上げ層 (L) から管内への水の流量 $\mathrm{QWL}(\mathrm{L})$ を仮定する。

3. 仕上げ層 $(\mathrm{L})$ から管内への水の流入に付随するガ スの流量 QGL $(\mathrm{L})$ を計算する。

4. 管内垂直方向の水とガスの流量 QQW (I), QQG (I)を求める。

5. 各仕上げ層の中央深度に対応する坑底圧 PWFL （L）を最下部坑底圧から順次, ORKISZEWSKI(1967) の垂直二相流圧力損失式を使って求める。

6. 地層圧 $\mathrm{PL}(\mathrm{L})$ と PWFL(L)加ら新たに管内への 水の流量 $\mathrm{QWL}$ (L)を求める。

7. QWL' (L)の合計が QWTに収斂したときループ
から出て，11.へ飛ぶ。

8. $\mathrm{QWL}^{\prime}(\mathrm{L})$ の合計と QWT との差から PWFL(L) の修正值 $\mathrm{PWFL}$ (L)を求ぬる。

9. $\mathrm{PL}(\mathrm{L})$ と $\mathrm{PWFL}$ (L)から $\mathrm{QWL}(\mathrm{L})$ を計算する。

10. 3. 戻る。

11. $Q W L^{\prime}(L)$ に付随するガスの流量 $Q G L^{\prime}$ (L) を計 算する。

12. 水の生産量をQWTとしたときの各仕上げ層か らの水の産出量は $Q W L^{\prime}(\mathrm{L})$, ガスの産出量は QGL' (L)，坑底压はPWFL(L)となる。

自噴又はガスリフト採収のときはさらにセパレーター までの圧力損失を BEGGS and BRILL (1973) の式で 計算し, 接点解析法で真の QWT を求める。

\section{4. 使用方法}

開発計画を立てるとき，経済性評価の面から各坑井の 生産量を推定する必要がある。生産に移行してからも産 量調整などで将来の予測ができれば有益であろう。産量 推定シミュレーターを開発した理由がそこにある。また 


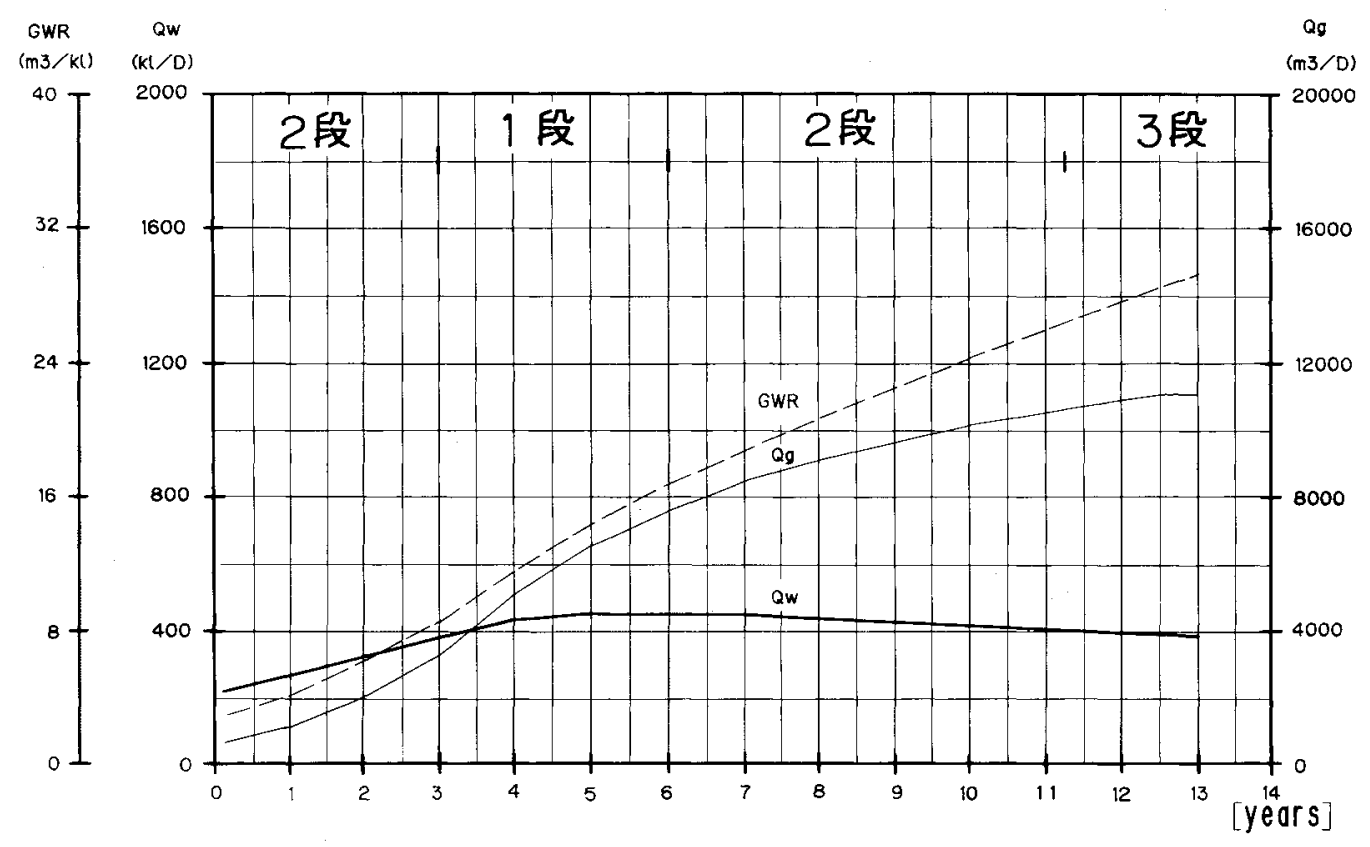

図 3 Forecast $(\mathrm{NCODE}=3)$

表 1 聍留層デー夕

\begin{tabular}{|c|c|c|c|c|}
\hline 孔 & 隙 & 率 & $\begin{array}{l}\text { 砂 岩 } \\
\text { 泥 岩 }\end{array}$ & $\begin{array}{l}0.35 \\
0.43\end{array}$ \\
\hline 浸 & 透 & 率 & $\begin{array}{l}\text { 㔔岩 } \\
\text { 泥岩 }\end{array}$ & $\begin{array}{r}200[\mathrm{md}] \\
0.002[\mathrm{md}]\end{array}$ \\
\hline 砂 & 岩 & 含 & 率 & 0.3 \\
\hline 泥 & 岩 & の & 枚 数 & 60 \\
\hline
\end{tabular}

表 2 坑井データ

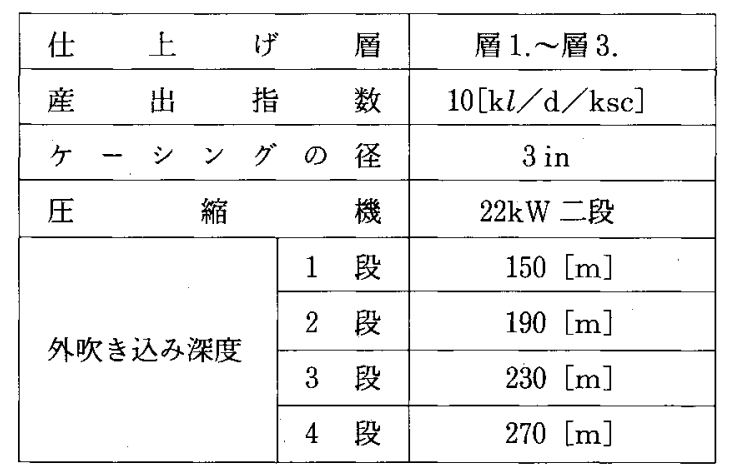

このシミュレーターを使ってケース・スタディを行う ことで最適な坑井を設計できる。逆に，既存の坑井につ いて各仕上げ層の産出量と坑底压を計算できることか
ら，坑井テストの解析にあ使用可能である。 これらの使用方法の例を以下に記す。

例 1. 生産量の予測

ある貯留層に坑井を掘削し，アンカーパイプで 3 層を 同時に仕上げたとして生産量の予测を行った。坑井によ る排出領域はほぼ $1000 \mathrm{~m}$ 四方である。仕上げ層の全層 厚は $300 \mathrm{~m}$, 上端の深度は $700 \mathrm{~m}$ である。㑏留層を XY 方向それぞれ 5 分割, Z 万向 3 分割して坑井をその中央 に配置した。

貯留層デー夕を表 1 ，坑井デー夕を表 2 に示す。3 枚 の仕上げ層は咛留層データとして同じ値をとる。初期 值として地層压とガスの飽和率を表 3 のように設定し た。

まず，生産方式を $\mathrm{NCODE}=3$ に指定して最適なケー スでの生産量を計算してみた。その結果を図 3 に示す。 生産が進むに従ってガス吹き込み段数が変化している。 生産開始から 3 年間は水位が高くてもガス水比が小さい ために 2 段にガスを吹き込みガスリフトを掛けている。 3 年経過するとガス亦比が上昇し，1段にガスを吹き込 むときが最適となる。さらに生産が進み水位が低下する とガス吹き込み深度は 2 段，3段と深くなる。

生産開始から 3 年が経過すると自噴するようになる。 そこで 4 年目から自噴 $(\mathrm{NCODE}=1)$ に切り換えてみ た。その結果が図 4 である。図 3 と図 4 ○比較からガス 水比が高くなると自噴でもガスリフト採収でも生産量に 


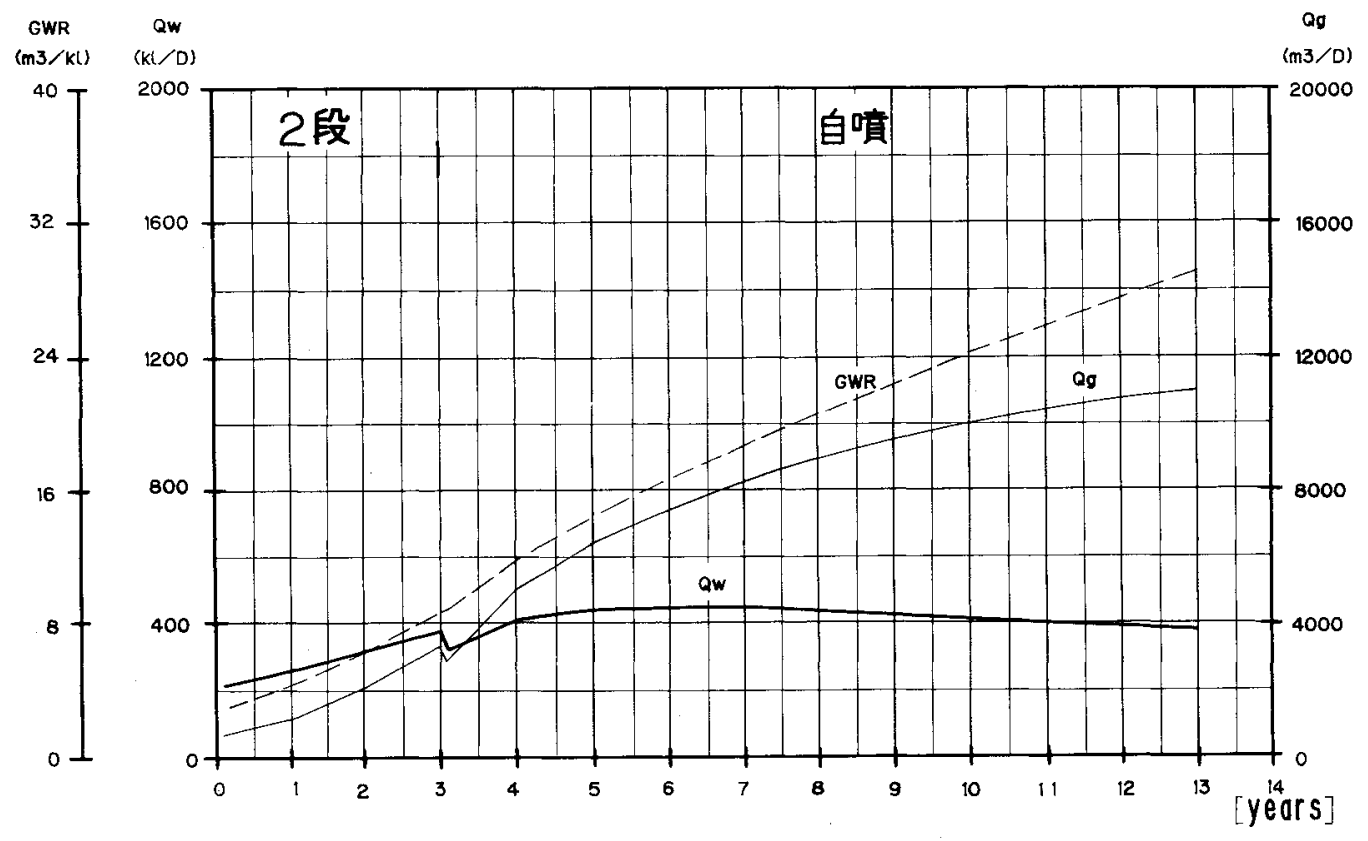

図 4 Forecast $(\mathrm{NCODE}=3.1)$

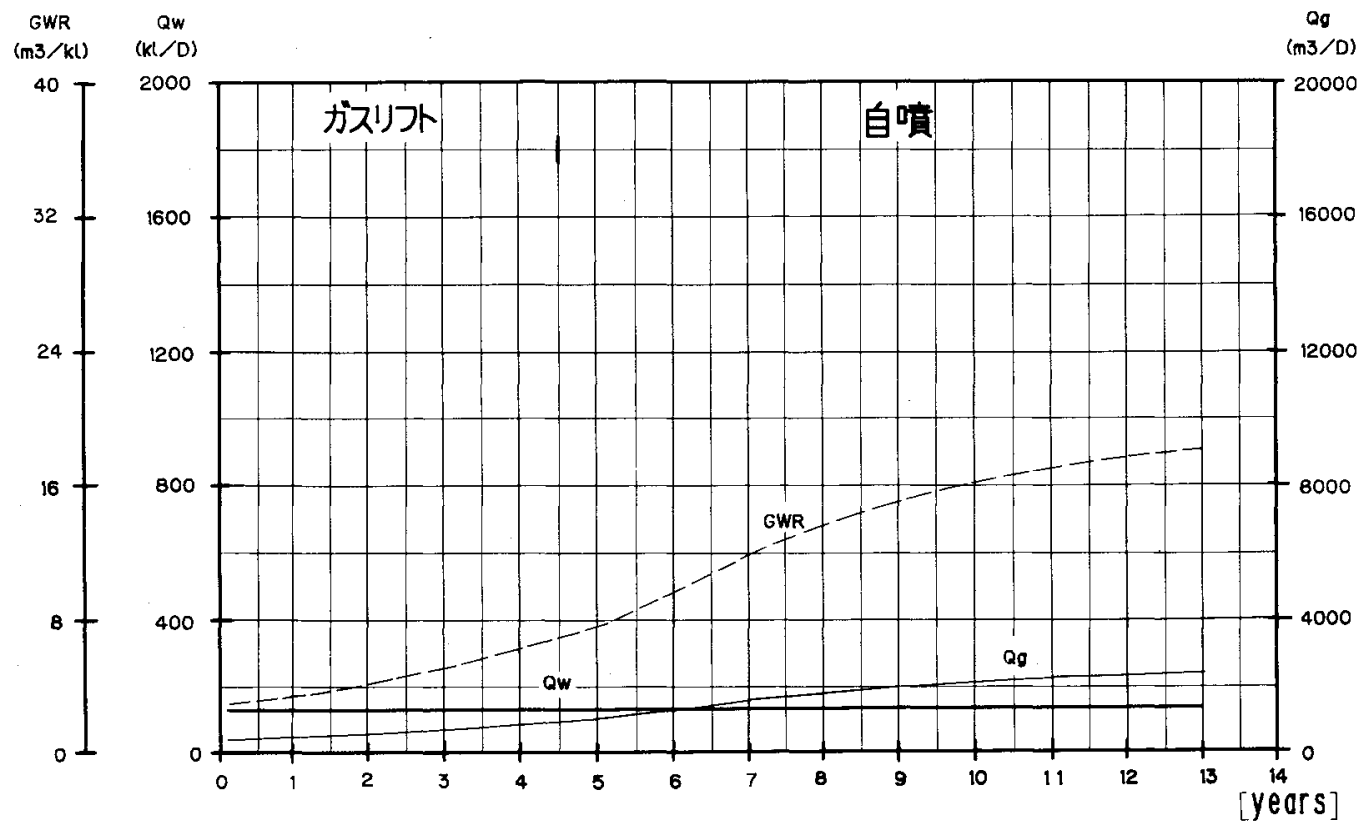

図 5 Forecast $(\mathrm{NCODE}=4)$ 
表 3 初 期 值

\begin{tabular}{|l|ll|l|}
\hline \multirow{2}{*}{ 地層 圧 } & 層 & 1. & $73.30[\mathrm{ksca}]$ \\
\cline { 2 - 4 } & 層 & 2. & $83.32[\mathrm{ksca}]$ \\
\cline { 2 - 3 } & 層 & 3. & $93.34[\mathrm{ksca}]$ \\
\hline \multirow{2}{*}{ ガスの飽和率 } & 砂 & 岩 & 0.003 \\
\cline { 2 - 3 } & 泥 & 岩 & 0.006 \\
\hline
\end{tabular}

表 4 ケース・スタディ(圧縮機, ケーシング)

\begin{tabular}{|c|c|c|c|}
\hline \multirow{2}{*}{} & \multicolumn{3}{|c|}{ ケーシング の 径 } \\
\cline { 2 - 4 } & $3 \mathrm{in}$. & $4 \mathrm{in}$. & $51 / 2 \mathrm{in}$. \\
\hline $11 \mathrm{~kW}$ 圧縮機 & 揚水不可 & 揚水不可 & 揚水不可 \\
\hline $22 \mathrm{~kW}$ 圧縮機 & $216[\mathrm{k} l / \mathrm{d}]$ & $223[\mathrm{k} l / \mathrm{d}]$ & $185[\mathrm{k} l / \mathrm{d}]$ \\
\hline $37 \mathrm{~kW}$ 圧縮機 & $249[\mathrm{k} l / \mathrm{d}]$ & $259[\mathrm{k} l / \mathrm{d}]$ & $222[\mathrm{k} l / \mathrm{d}]$ \\
\hline
\end{tabular}

大差が無いことがわかる。

地盤沈下抑制又はガスバランスから生産量を制限する ことがある。生産水量を $130 \mathrm{k} l / \mathrm{d}$ に制限して 13 年間生 産を続けるとガスの生産量はどのように変化するかを調 べた。その結果を図 5 に示す。制限せずに生産した場合 と比べてガス水比の上昇速度が小さくなる。そのため自 噴採収に切り換えられる時期が生産開始から 4 年半後と 遅くなる。

このように眝留層の条件と坑井仕様が定まれば生産方 式を指定して生産量を予测することができる。

例 2. 坑井の設計

前述のように外吹き込み方式を採用するときは坑井の 設計段階でガスリフトの重要な点が決まる。ケーシング の径やガスリフト用圧縮機は特に重要で生産に直接影響 する。そこで, この 2 項目を変化させたとき生産量がど のようになるか産量推定シミニレーターを使いケース・ スタディを行った。そのときの貯留層は例 1 で設定した あの（表 1)をそのまま使い, 坑井はケーシングの径と 圧縮機以外, 表 2 の仕様とした。初期值も同様に表 3 を 設定した。一般に使用されるケーシングの径は3in., 4 in., $5 \frac{1}{2}$ in. である。ガスリフト用圧縮機には動力が $11 \mathrm{~kW}, 22 \mathrm{~kW}, 37 \mathrm{~kW} の 3$ 機種を選んだ。

ケース・ス夕ディから求められた初期の生産水量を表 4 にまとめた。動力が $11 \mathrm{~kW}$ の圧縮機では揚水が不可能 である。ケーシングの径が $4 \mathrm{in}$. で压縮機が動力 $37 \mathrm{~kW}$ のとき揚水量は最大になる。

実際に坑井を設計する場合は初期の揚水量だけでな く, 長期間にわたる生産の推移を計算し, 結果の信頼性 を把握する必要がある。

例 3. 坑井テストの解析

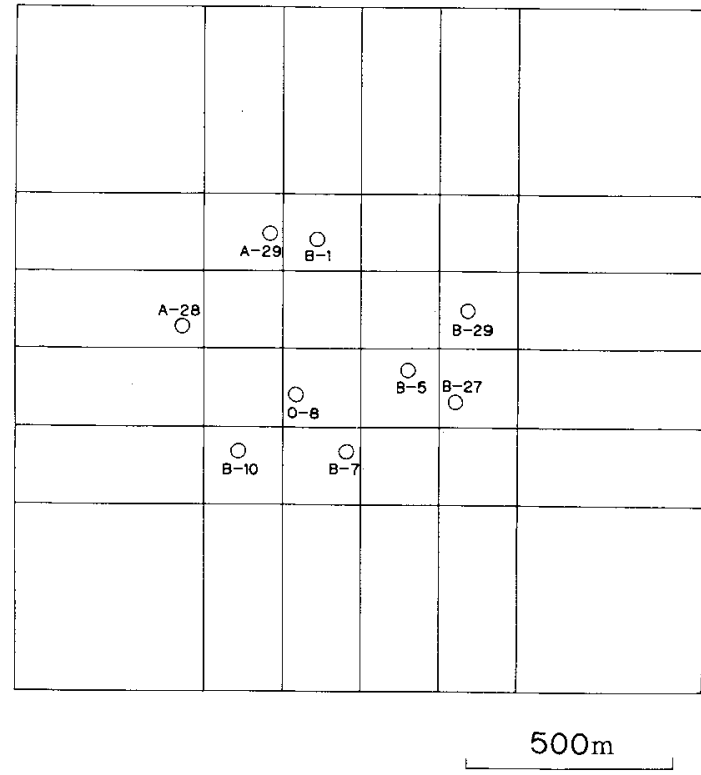

図 6 坑井配置

B-29号井の生産開始時期にはすでに図6に示す生産 井や压入井が附近に存在した。表 5 にそれらの坑井の 仕上げ層を表わす。図7には生産開始から Pressure Build-up Test までの B-29号井の生産量を図示する。 流動坑底圧はPBUT の直前に, 静止坑底圧はPBUT の後に測定した。その測定值と産量推定シミュレーター によって求めた坑底压の計算值とのマッチングを行い, 地層圧やガスの䭂和率, 産出指数を推定した。マッチン グの結果を図 8 に示す。表 6 に推定された地層圧, ガス の飽和率, 産出指数を記す。また, 生産状態での各仕上 げ層からの産出量を図 9 に, 静止状態での産出量を図10 に示す。図 9 を見ると，ガスの産出量は大田代層下部 （層 4）が最大であり，梅ヶ瀬層中部（層 1）では生産状 態であってあガスと水が地層へ逆流している。地層压の アンバランスから生産を止めても図10の上うに梅ヶ瀬層 下部（層 2)，大田代層上部（層 3）, 下部（層 4）加 梅ヶ瀬層中部（層 1）へ多量のガスと水が流れる。

以上のように，このシミュレーターを使えば他坑井の 影響を入れて生産量之坑底圧の測定結果から貯留首の性 状や仕上げ層ごとの産出量を推定できる。

\section{まとめ}

産量推定シミュレーターを開発したことにより, 南関 東ガス田に掘削された多層アンカー仕上げ坑井の生産量 を鉱床のエネルギー及び坑井の生産能力から経時的に予 測することが可能になった。開発計画を立案し，その経 


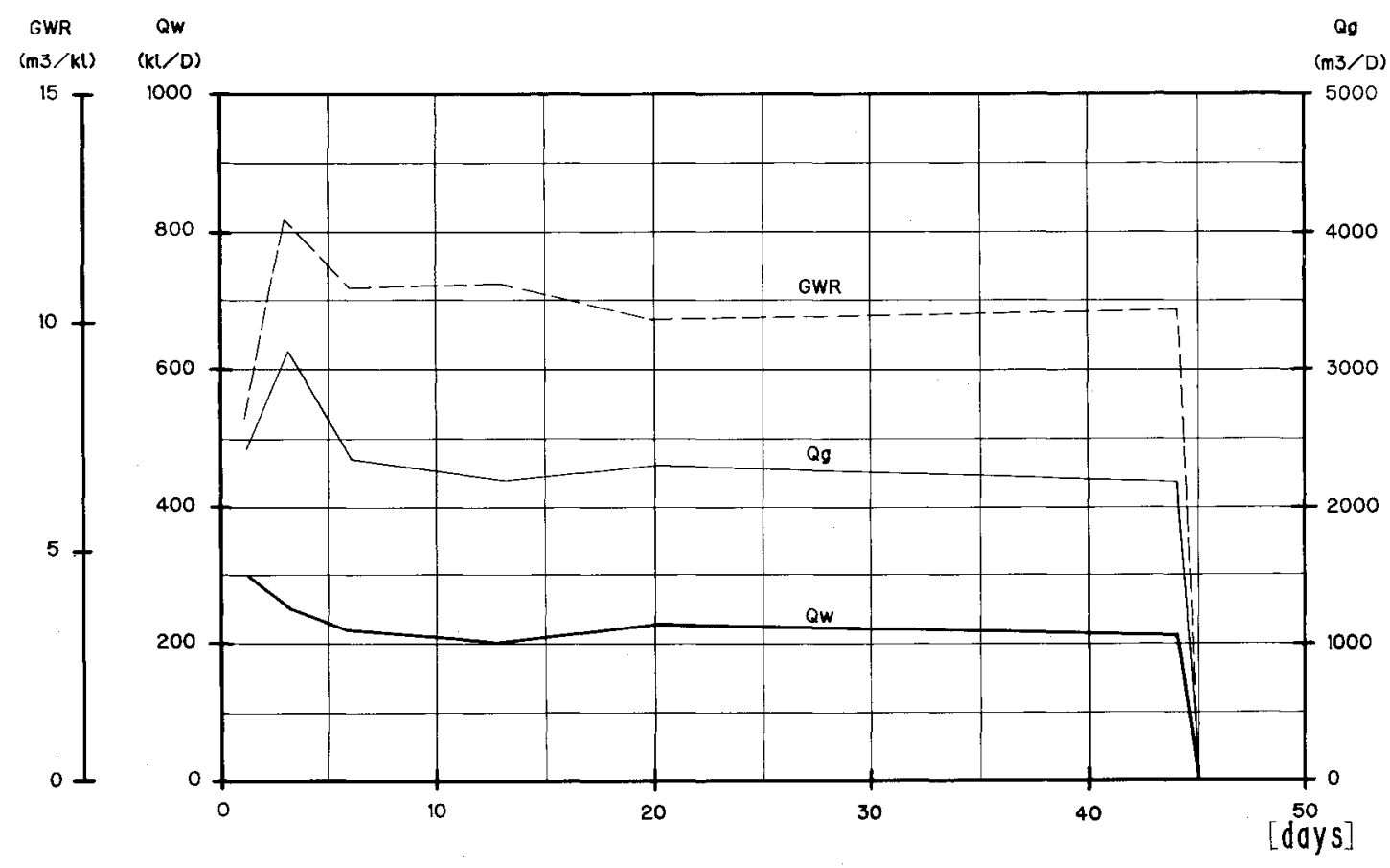

図 7 Production rate $(B-29)$

表 5 仕上げ層

\begin{tabular}{|c|c|c|c|c|c|c|c|c|c|c|c|}
\hline & \multirow{2}{*}{ 地 層 名 } & \multicolumn{4}{|c|}{ 生 産 井 } & \multicolumn{5}{|c|}{ 圧 入 井 } \\
\hline & & & $B-29$ & $B-10$ & $A-28$ & $A-29$ & $B-1$ & $B-5$ & $B-7$ & $\mathrm{~B}-27$ & $0-8$ \\
\hline 層 & 1. & 梅 ケ瀬 層 中部 & 0 & 0 & & & 0 & 0 & 0 & 0 & \\
\hline 層 & 2. & 梅 ケ 瀬 層 下部 & 0 & 0 & & & 0 & 0 & 0 & & \\
\hline 層 & 3. & 大田代層上部 & 0 & & 0 & 0 & & & & & \\
\hline 層 & 4. & 大田代 層下 部 & O & & 0 & 0 & & & & & 0 \\
\hline
\end{tabular}

表6 マッチングの結果

\begin{tabular}{|c|c|c|c|c|c|c|}
\hline & \multirow{2}{*}{ 地 層 名 } & \multirow{2}{*}{$\frac{\text { 地 層 圧 }}{[\mathrm{ksca}]}$} & \multicolumn{2}{|c|}{ ガスの飽和率 } & \multirow{2}{*}{$\frac{\text { 産出指 数 }}{[\mathrm{k} l / \mathrm{d} / \mathrm{ksc}]}$} \\
\hline & & & & 砂 岩 & 泥 岩 & \\
\hline 層 & 1. & 梅 ケ 瀬 層 中 部 & 19.0 & 0.015 & 0.024 & 30.0 \\
\hline 層 & 2. & 梅 ケ 瀬 層 下部 & 35.5 & 0.016 & 0.024 & 35.0 \\
\hline 層 & 3. & 大田代層上部 & 52.0 & 0.008 & 0.005 & 10.0 \\
\hline 層 & 4. & 大田代層下部 & 63.0 & 0.015 & 0.013 & 5.0 \\
\hline
\end{tabular}

闵性を評価するときにこれが役立つ。また，このシミュ レーターを使えば目標とする生産量を達成するための坑 井仕様を見出すことあできる。このように産量推定シミュ レーターは開発計画を立てる上で有用な道具となる。
さらに坑井テストの解析を行うとき，その坑井が隣接 した他坑井の生産又は圧入の影響を受けていても，この シミュレーターで解析す机ば地層の状況をある程度正確 に把握できる。 


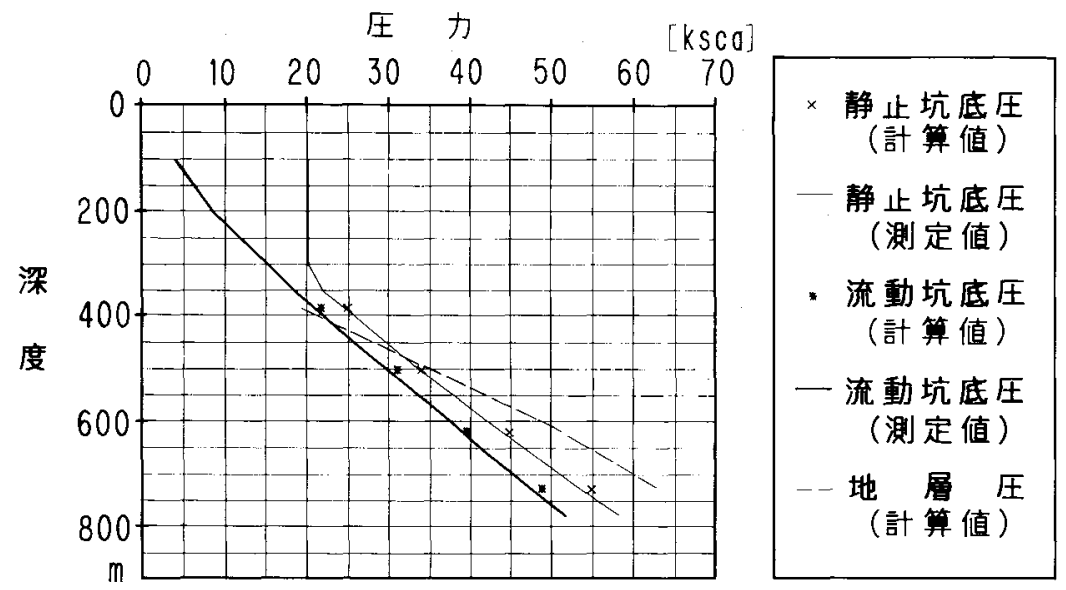

図 8 坑 底 圧

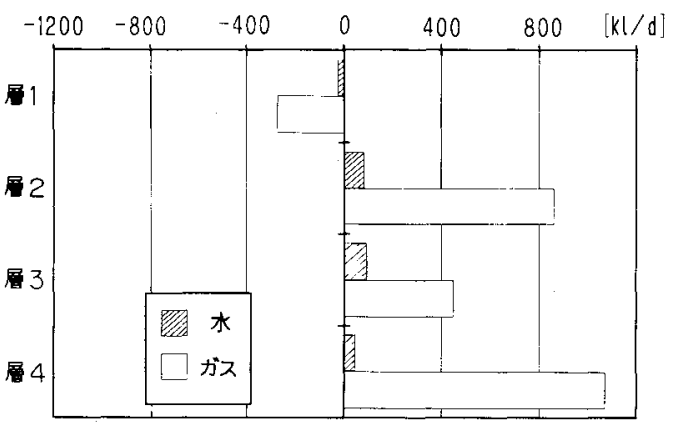

図9 産出量 (flowing)

\section{参 考 文 献}

BegGs, H. D. and BRILL, J. P., 1973: A Study of Two-Phase Flow in Inclined Pipes, JPT, May.

BRown, K. B., 1977: The Technology of Artificial Lift Methods, 1, Petroleum Publishing

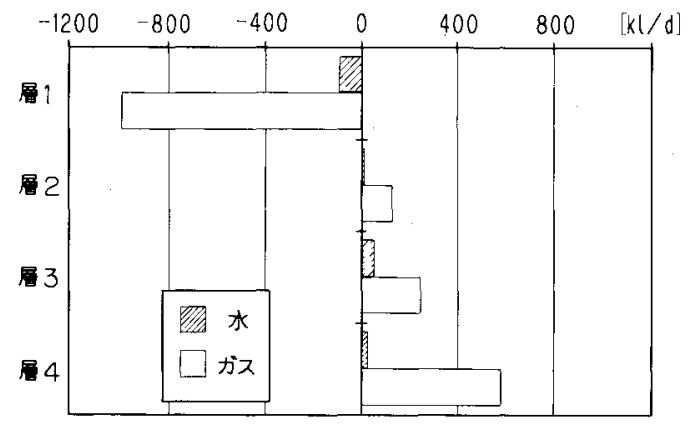

図 10 産出量 (static)

Company.

ORKISZEWSKI, J., 1967: Predicting Two-Phase Pressure Drops in Vertical Pipe, JPT, June. 杉原豊, 1987: パソコンを使ったガスリフト効果の計 算システム，石技誌，52(6)，520-526.

田崎義行, 1988: 水溶性天然ガ ス 鉱床と sand / silt system. 石技誌，53(4)，256-264. 